\title{
Carabodes azoricus
}

\author{
Assessment by: Nunes, R. \& Borges, P.A.V.
}

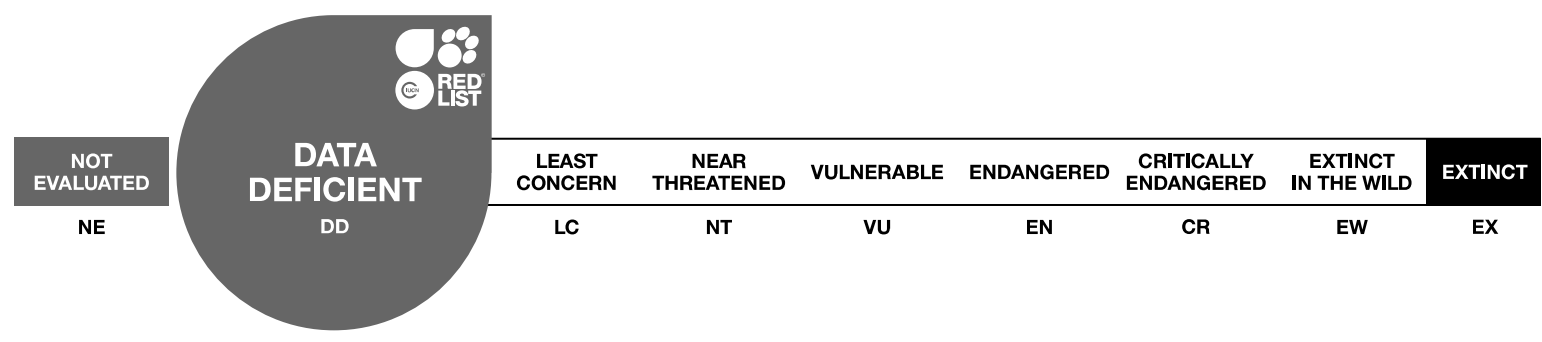

View on www.iucnredlist.org

Citation: Nunes, R. \& Borges, P.A.V. 2020. Carabodes azoricus. The IUCN Red List of Threatened Species 2020: e.T119420152A119441623. https://dx.doi.org/10.2305/IUCN.UK.20203.RLTS.T119420152A119441623.en

Copyright: (C 2020 International Union for Conservation of Nature and Natural Resources Reproduction of this publication for educational or other non-commercial purposes is authorized without prior written permission from the copyright holder provided the source is fully acknowledged.

Reproduction of this publication for resale, reposting or other commercial purposes is prohibited without prior written permission from the copyright holder. For further details see Terms of Use.

The IUCN Red List of Threatened Species ${ }^{T M}$ is produced and managed by the IUCN Global Species Programme, the IUCN Species Survival Commission (SSC) and The IUCN Red List Partnership. The IUCN Red List Partners are: Arizona State University; BirdLife International; Botanic Gardens Conservation International; Conservation International; NatureServe; Royal Botanic Gardens, Kew; Sapienza University of Rome; Texas A\&M University; and Zoological Society of London.

If you see any errors or have any questions or suggestions on what is shown in this document, please provide us with feedback so that we can correct or extend the information provided. 


\section{Taxonomy}

\begin{tabular}{|c|c|c|c|c|}
\hline Kingdom & Phylum & Class & Order & Family \\
\hline Animalia & Arthropoda & Arachnida & Oribatida & Carabodidae \\
\hline
\end{tabular}

Scientific Name: Carabodes azoricus Pérez-Íñigo \& Pérez-Íñigo Jr., 1996

\section{Assessment Information}

Red List Category \& Criteria: $\quad$ Data Deficient ver 3.1

Year Published: 2020

Date Assessed: $\quad$ March 31, 2018

\section{Justification:}

Carabodes azoricus is an endemic species of the Azores (Portugal), having been described from one location in Terceira island. From the species' description, it potentially has a very small Extent of Occurrence $\left(4 \mathrm{~km}^{2}\right)$ and Area of Occupancy $\left(4 \mathrm{~km}^{2}\right)$, but these are likely underestimates, as this species probably has a wider distribution through the soil component of the island. It can be assumed that this species is affected by human activities and invasive plant species, which alter the natural structure and composition of the soil. Future climatic changes and increased risk of droughts will also affect this species. The present situation of this species needs to be further assessed and further research is needed into its population, distribution, threats, ecology and life history. Conservation of natural habitats and invasive species control could potentially aid this species conservation. Based upon the incomplete knowledge regarding this species population, distribution, threats and ecology, this species is assessed as Data Deficient (DD).

\section{Geographic Range}

\section{Range Description:}

Carabodes azoricus is an endemic oribatid mite species known from Terceira island (Azores, Portugal) (Borges et al. 2010), described from the Nature Reserve of Caldeira Sta. Bárbara e Mistérios Negros. From the species' description, the Extent of Occurrence (EOO) would be $c a 4 \mathrm{~km}^{2}$ and the Area of Occupancy (AOO) would be $4 \mathrm{~km}^{2}$.

\section{Country Occurrence:}

Native, Extant (resident): Portugal (Azores) 


\section{Distribution Map}

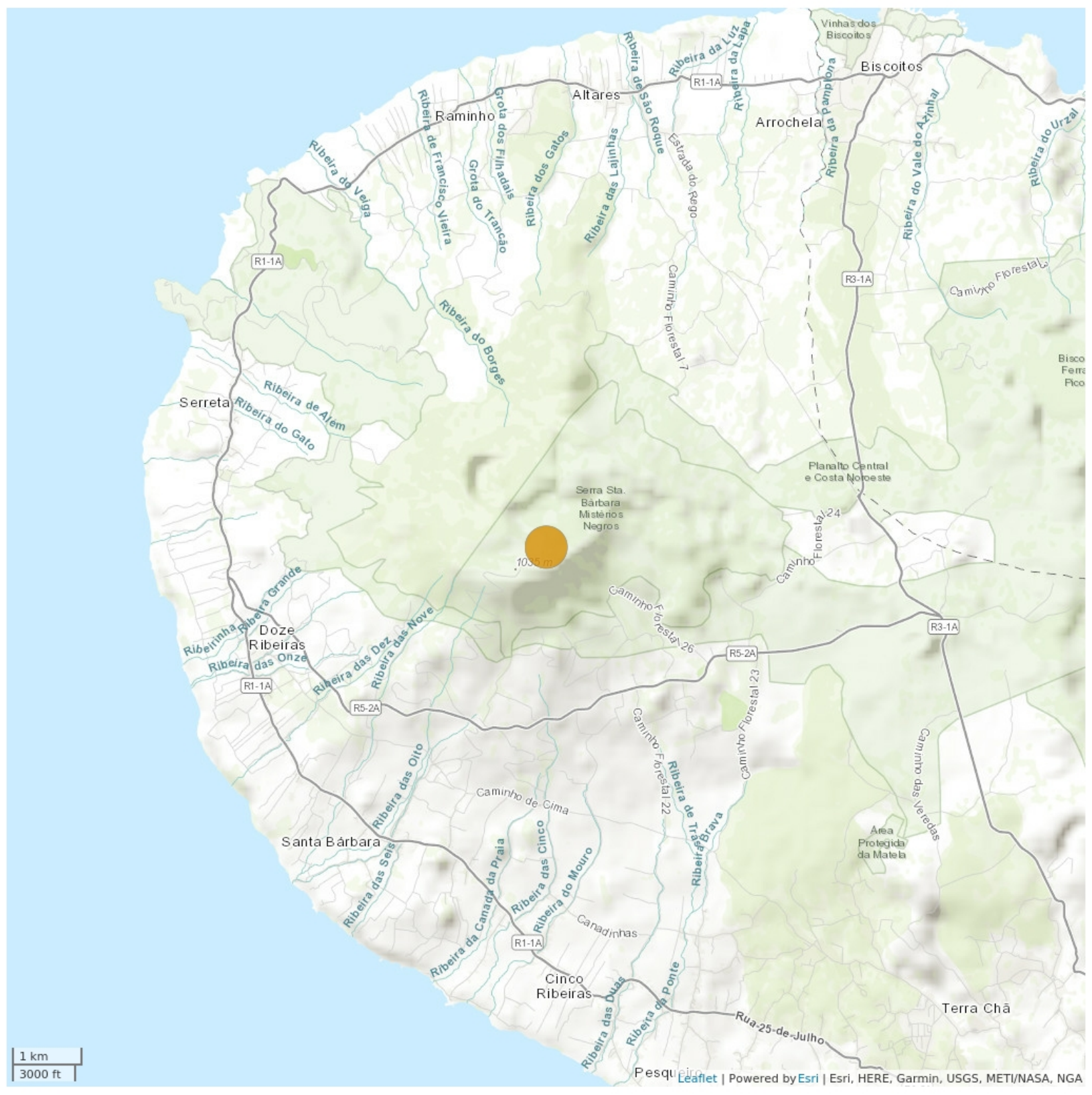

Legend

EXTANT (RESIDENT)
Compiled by:

Azorean Biodiversity Group 2018
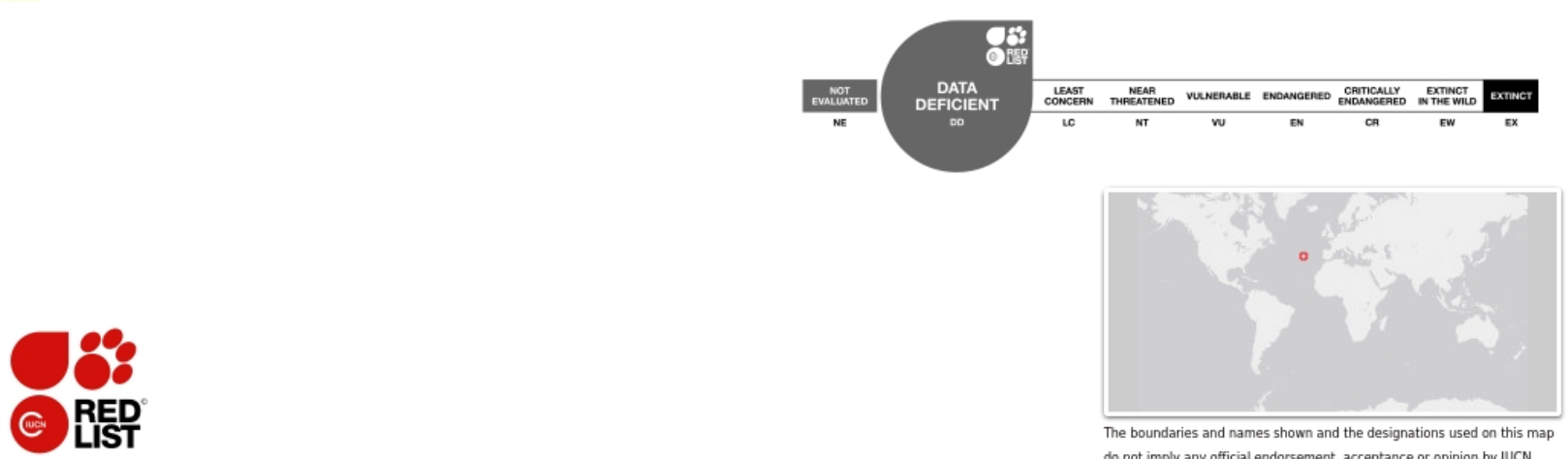


\section{Population}

No current population size estimates exist for this species. As an oribatid mite, this species is likely common and widespread in the soil habitat.

Current Population Trend: Unknown

\section{Habitat and Ecology (see Appendix for additional information)}

The ecology and traits of this species are unknown. Oribatid mites are associated with organic matter in most terrestrial ecosystems, being found throughout the soil profile, in surface litter, on grasses, shrubs or in the bark and leaves of trees, among other habitats. Oribatida are also one of the most numerically dominant arthropod groups in the organic horizons of most soils (Behan-Pelletier 1999). Carabodes azoricus was collected from pitfall traps in the soil.

Systems: Terrestrial

\section{Threats (see Appendix for additional information)}

A lack of information regarding the present range of this species precludes an assessment of potential threats. Nevertheless, it can be assumed that this species will be affected by future habitat declines as a consequence of climate change (Ferreira et al., 2016) and increased droughts. Other factors that affect habitat quality like land use changes, urbanisation, pesticides and nutrient loads or invasive plants might also affect this species.

\section{Conservation Actions (see Appendix for additional information)}

The species is not protected by regional law, but part of its habitat is in a regionally protected area (Natural Park of Terceira). Land-use changes are likely one of the main current and future threats, and conservation of native habitats and invasive species control could potentially aid this species' conservation. Further research is needed into its population, distribution, threats, ecology and life history. It is also necessary to develop a monitoring plan for the invertebrate community in order to contribute to the conservation of this species.

\section{Credits}

Assessor(s): $\quad$ Nunes, R. \& Borges, P.A.V.

Reviewer(s): $\quad$ Danielczak, A.

Authority/Authorities: IUCN SSC Spider and Scorpion Specialist Group 


\section{Bibliography}

Behan-Pelletier, V.M. 1999. Oribatid mite biodiversity in agroecosystems: role for bioindication. Agriculture, Ecosystems \& Environment 74(1-3): 411-423.

Borges, P.A.V., Costa, A., Cunha, R., Gabriel, R., Gonçalves, V., Martins, A.F., Melo, I., Parente, M., Raposeiro, P., Rodrigues, P., Santos, R.S., Silva, L., Vieira, P. and Vieira, V. 2010. A list of the terrestrial and marine biota from the Azores. Princípia, Cascais.

Ferreira, M.T., Cardoso, P., Borges, P.A.V., Gabriel, R., Azevedo, E.B., Reis, F., Araújo, M.B. and Elias, R.B. 2016. Effects of climate change on the distribution of indigenous species in oceanic islands (Azores).

Climate Change 138(3-4): 603-615.

IUCN. 2020. The IUCN Red List of Threatened Species. Version 2020-3. Available at: www.iucnredlist.org. (Accessed: 10 December 2020).

\section{Citation}

Nunes, R. \& Borges, P.A.V. 2020. Carabodes azoricus. The IUCN Red List of Threatened Species 2020:

e.T119420152A119441623. https://dx.doi.org/10.2305/IUCN.UK.2020-

3.RLTS.T119420152A119441623.en

\section{Disclaimer}

To make use of this information, please check the Terms of Use.

\section{External Resources}

For Supplementary Material, and for Images and External Links to Additional Information, please see the Red List website. 


\section{Appendix}

\section{Habitats}

(http://www.iucnredlist.org/technical-documents/classification-schemes)

\begin{tabular}{|c|c|c|c|}
\hline Habitat & Season & Suitability & $\begin{array}{l}\text { Major } \\
\text { Importance? }\end{array}$ \\
\hline 1. Forest $->$ 1.4. Forest - Temperate & Resident & Suitable & Yes \\
\hline 3. Shrubland -> 3.4. Shrubland - Temperate & Resident & Suitable & Yes \\
\hline 4. Grassland $->$ 4.4. Grassland - Temperate & Resident & Suitable & Yes \\
\hline
\end{tabular}

\section{Threats}

(http://www.iucnredlist.org/technical-documents/classification-schemes)

\begin{tabular}{|c|c|c|c|c|}
\hline Threat & Timing & Scope & Severity & Impact Score \\
\hline \multirow{3}{*}{$\begin{array}{l}\text { 2. Agriculture \& aquaculture }->2.1 \text {. Annual \& } \\
\text { perennial non-timber crops }->2.1 .2 \text {. Small-holder } \\
\text { farming }\end{array}$} & Ongoing & Minority (50\%) & $\begin{array}{l}\text { Slow, significant } \\
\text { declines }\end{array}$ & Low impact: 5 \\
\hline & Stresses: & \multirow{2}{*}{\multicolumn{3}{|c|}{$\begin{array}{l}\text { 1. Ecosystem stresses }->1.1 \text {. Ecosystem conversion } \\
\text { 1. Ecosystem stresses }->1.2 \text {. Ecosystem degradation }\end{array}$}} \\
\hline & & & & \\
\hline \multirow{3}{*}{$\begin{array}{l}\text { 2. Agriculture \& aquaculture }->2.3 \text {. Livestock farming } \\
\& \text { ranching }->2.3 .2 \text {. Small-holder grazing, ranching or } \\
\text { farming }\end{array}$} & Ongoing & Minority (50\%) & Slow, significant & Low impact: 5 \\
\hline & Stresses: & \multirow{2}{*}{\multicolumn{3}{|c|}{$\begin{array}{l}\text { 1. Ecosystem stresses }->1.1 \text {. Ecosystem conversion } \\
\text { 1. Ecosystem stresses }->1.2 \text {. Ecosystem degradation }\end{array}$}} \\
\hline & & & & \\
\hline \multirow{2}{*}{$\begin{array}{l}\text { 8. Invasive and other problematic species, genes \& } \\
\text { diseases -> 8.1. Invasive non-native/alien } \\
\text { species/diseases }->8.1 .1 \text {. Unspecified species }\end{array}$} & Ongoing & Minority (50\%) & $\begin{array}{l}\text { Slow, significant } \\
\text { declines }\end{array}$ & Low impact: 5 \\
\hline & Stresses: & \multicolumn{3}{|c|}{ 1. Ecosystem stresses $->1$ 1.2. Ecosystem degradation } \\
\hline \multirow{3}{*}{$\begin{array}{l}\text { 9. Pollution }->9.3 \text {. Agricultural \& forestry effluents }-> \\
\text { 9.3.1. Nutrient loads }\end{array}$} & Ongoing & Minority (50\%) & $\begin{array}{l}\text { Slow, significant } \\
\text { declines }\end{array}$ & Low impact: 5 \\
\hline & Stresses: & \multirow{2}{*}{\multicolumn{3}{|c|}{$\begin{array}{l}\text { 1. Ecosystem stresses }->1.2 \text {. Ecosystem degradation } \\
\text { 1. Ecosystem stresses }->1.3 \text {. Indirect ecosystem effects }\end{array}$}} \\
\hline & & & & \\
\hline \multirow[t]{2}{*}{$\begin{array}{l}\text { 9. Pollution }->9.3 \text {. Agricultural \& forestry effluents }-> \\
\text { 9.3.3. Herbicides and pesticides }\end{array}$} & Ongoing & Minority (50\%) & $\begin{array}{l}\text { Very rapid } \\
\text { declines }\end{array}$ & $\begin{array}{l}\text { Medium } \\
\text { impact: } 7\end{array}$ \\
\hline & Stresses: & \multicolumn{3}{|c|}{ 2. Species Stresses -> 2.1. Species mortality } \\
\hline \multirow[t]{4}{*}{$\begin{array}{l}\text { 11. Climate change \& severe weather }->11.1 \text {. Habitat } \\
\text { shifting \& alteration }\end{array}$} & Future & $\begin{array}{l}\text { Majority (50- } \\
90 \%)\end{array}$ & $\begin{array}{l}\text { Slow, significant } \\
\text { declines }\end{array}$ & Low impact: 4 \\
\hline & Stresses: & \multirow{3}{*}{\multicolumn{3}{|c|}{$\begin{array}{l}\text { 1. Ecosystem stresses } \rightarrow \text { 1.1. Ecosystem conversion } \\
\text { 1. Ecosystem stresses }->1.2 \text {. Ecosystem degradation } \\
\text { 1. Ecosystem stresses }->1.3 \text {. Indirect ecosystem effects }\end{array}$}} \\
\hline & & & & \\
\hline & & & & \\
\hline \multirow[t]{3}{*}{$\begin{array}{l}\text { 11. Climate change \& severe weather -> 11.2. } \\
\text { Droughts }\end{array}$} & Future & $\begin{array}{l}\text { Majority (50- } \\
90 \%)\end{array}$ & $\begin{array}{l}\text { Slow, significant } \\
\text { declines }\end{array}$ & Low impact: 4 \\
\hline & Stresses: & \multicolumn{3}{|c|}{ 1. Ecosystem stresses $->1.2$. Ecosystem degradation } \\
\hline & & \multicolumn{3}{|c|}{ 1. Ecosystem stresses $->1.3$. Indirect ecosystem effects } \\
\hline
\end{tabular}




\title{
Conservation Actions in Place
}

(http://www.iucnredlist.org/technical-documents/classification-schemes)

\begin{tabular}{|l|}
\hline Conservation Action in Place \\
\hline In-place research and monitoring \\
\hline Action Recovery Plan: No \\
\hline Systematic monitoring scheme: No \\
\hline In-place land/water protection \\
\hline Conservation sites identified: No \\
\hline Occurs in at least one protected area: Yes \\
\hline
\end{tabular}

\section{Conservation Actions Needed}

(http://www.iucnredlist.org/technical-documents/classification-schemes)

\section{Conservation Action Needed}

2. Land/water management -> 2.1. Site/area management

2. Land/water management -> 2.2. Invasive/problematic species control

5. Law \& policy -> 5.1. Legislation -> 5.1.3. Sub-national level

\section{Research Needed}

(http://www.iucnredlist.org/technical-documents/classification-schemes)

\section{Research Needed}

1. Research $->1.2$. Population size, distribution \& trends

1. Research -> 1.3. Life history \& ecology

1. Research -> 1.5. Threats

3. Monitoring $->$ 3.1. Population trends

3. Monitoring $->3.4$. Habitat trends

\section{Additional Data Fields}

\author{
Distribution \\ Estimated area of occupancy (AOO) $\left(\mathrm{km}^{2}\right): 4$ \\ Continuing decline in area of occupancy (AOO): Unknown \\ Extreme fluctuations in area of occupancy (AOO): Unknown \\ Estimated extent of occurrence (EOO) $\left(\mathrm{km}^{2}\right): 4$
}




\section{Distribution}

Continuing decline in extent of occurrence (EOO): Unknown

Extreme fluctuations in extent of occurrence (EOO): Unknown

Continuing decline in number of locations: Unknown

Extreme fluctuations in the number of locations: Unknown

Lower elevation limit $(\mathrm{m}): 925$

Upper elevation limit (m): 975

Population

Continuing decline of mature individuals: Unknown

Extreme fluctuations: Unknown

Population severely fragmented: Unknown

Habitats and Ecology

Continuing decline in area, extent and/or quality of habitat: Unknown 


\section{The IUCN Red List Partnership}

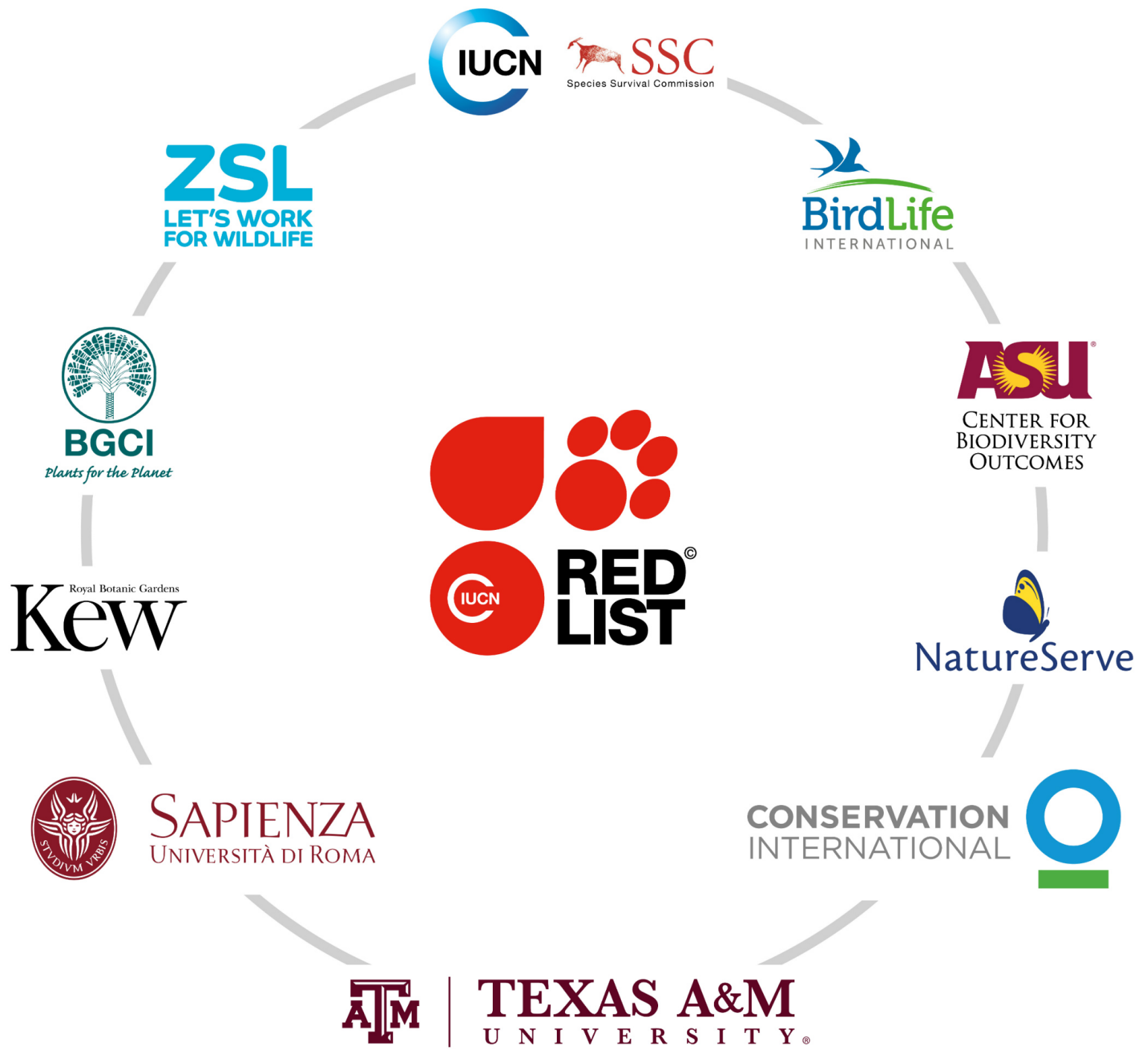

The IUCN Red List of Threatened Species ${ }^{\mathrm{TM}}$ is produced and managed by the IUCN Global Species Programme, the IUCN Species Survival Commission (SSC) and The IUCN Red List Partnership.

The IUCN Red List Partners are: Arizona State University; BirdLife International; Botanic Gardens Conservation International; Conservation International; NatureServe; Royal Botanic Gardens, Kew; Sapienza University of Rome; Texas A\&M University; and Zoological Society of London. 